\title{
The effect of vanilla flavoured calf starter on performance of Holstein calves
}

\author{
M.H. Fathi ${ }^{1}$, A. Riasi and A. Allahresani \\ Department of Animal Science, University of Birjand \\ Birjand, 97175/331, Iran
}

(Received 31 July 2008; revised version 18 November 2008; accepted 24 June 2009)

\begin{abstract}
Twenty one male Holstein calves were used to evaluate the effects of vanilla flavour added to starter on preweaning and postweaning calf performance. Following $3 \mathrm{~d}$ of colostrum and transition milk feeding, calves were assigned in a completely randomized design to two treatments including: 1. unflavoured starter and 2. flavoured starter. Calves were fed whole milk at $10 \%$ of the initial body weight daily and had free access to starter and water. The weaning criterion was defined as the calf age at a daily intake of $0.80 \mathrm{~kg}$ of starter for 2 days, consecutively. Calves fed flavoured starter weighed more at weaning and at the end of experiment and the preweaning average daily gains increased significantly compared with calves fed unflavoured starter. The starter consumption during the preweaning but not postweaning period was significantly higher in calves fed flavoured starter. The calves fed flavoured starter met weaning criteria at a younger age, so that they had 2 to 3 days shorter preweaning period $(\mathrm{P}<0.03)$. These findings demonstrate that supplementing starter with vanilla as a flavour agent is advantageous to calf performance.
\end{abstract}

KEY WORDS: calf, weaning age, growth rate, flavour, vanilla

\section{INTRODUCTION}

An important component in successful calf rearing programmes is an early transition to starter grain. Earlier consumption of starter grains allows for earlier weaning resulting in decreased labour costs and potentially lower feed costs while still achieving adequate growth (Davis and Drackley, 1998). Development of rumen papillae is aided by the fermentation of calf starter to VFA (Anderson et

\footnotetext{
${ }^{1}$ Corresponding author: e-mail: mhfathi@gmail.com
} 
al., 1987). Growth of rumen papillae aids in allowing the calf to change from a monogastric form of digestion to one characteristic of adult ruminants (Warner, 1991). When calves consume both calf starter and water at an early age, maturation of the rumen occurs at an earlier age compared with milk-feeding alone.

This progress toward maturation of the rumen allows calves to be weaned effectively at earlier age (Anderson et al., 1987). However, calves usually consume only small amounts of dry feed during the first few weeks of life. In order to increase intake of solid feeds, farmers usually apply different approaches like using a prestarter diet (Morrill, 1984) or add milk replacer to a complete starter diet (Winter, 1978), but these feeds are usually nearly as expensive as feeding milk replacer. Few studies have investigated the ability of different flavour agents in stimulating the feed and water intake by calves, but the using of vanilla flavour in calf starter that smacks the milk taste has not tested. Our hypothesis was that vanilla in the starter would increase calf dry feed intake and improve growth, and the objective of this study, therefore, was to investigate the effect of vanilla flavoured starter on feed intake, performance and weaning age of Holstein calves.

\section{MATERIAL AND METHODS}

\section{Animals and treatments}

Twenty one male Holstein calves, weighed more than $36 \mathrm{~kg}$, were separated from their mothers within $24 \mathrm{~h}$ of birth, weighed, moved into individual pens with wood shavings for bedding and fed 41 of colostrum over two feedings. Fresh colostrum from the dam was used for calves if it measured greater than $60 \mathrm{mg}$ of $\mathrm{Ig} / \mathrm{ml}$ of colostrums using a colostrometer. Otherwise, high-quality $(>60 \mathrm{mg}$ of $\mathrm{Ig} / \mathrm{ml})$ frozen colostrum was warmed to at least $26^{\circ} \mathrm{C}$ and fed. The calves were fed colostrum and transition milk (obtained from their mothers) for three days at $10 \%$ of initial body weight (BW), and then at this age, were randomly assigned to two treatments. Birth weights were similar for the unflavoured (UF) and flavoured (F) starter fed calves $(40.20 \pm 1.2$ and $41.0 \pm 1.0 \mathrm{~kg}$, respectively; $\mathrm{P}>0.10)$. The treatments were feeding 1. UF or 2 . F, containing $0.2 \%$ vanilla, DM basis, starter. Calves were fed whole milk, including milk from fresh and treated cows (i.e. "waste milk") at $10 \%$ of the initial BW daily, distributed evenly across the two feedings (04.00 and $16.00 \mathrm{~h}$ ) until weaned. The weaning process occurred when the calves had consumed $0.80 \mathrm{~kg}$ of starter/d for $2 \mathrm{~d}$, consecutively. They weaned by feeding 21 of whole milk twice daily for $4 \mathrm{~d}$, followed by complete weaning from milk on $\mathrm{d} 5$. The experiment was ended 3 weeks after weaning the calves. 
Starters that were offered from the age of three days, were consisted of grain processed with a hammer mill in pellet form, containing either vanilla flavour or unflavoured (Table 1). The starters were formulated to be isocaleric and

Table 1. Ingredient and nutrient composition of experimental diets

\begin{tabular}{|c|c|c|}
\hline \multirow{2}{*}{ Item } & \multicolumn{2}{|c|}{ Diet $^{1}$} \\
\hline & UF starter & F starter \\
\hline \multicolumn{3}{|l|}{ Ingredient, $\% D M$} \\
\hline lucerne hay & 15 & 15 \\
\hline maize, cracked & 24.5 & 24.5 \\
\hline barley, ground & 23 & 22.8 \\
\hline soyabean meal & 29 & 29 \\
\hline molasses & 6 & 6 \\
\hline oyster shell & 1 & 1 \\
\hline dicalcium phosphate & 0.5 & 0.5 \\
\hline vitamin/ trace-mineral mix $^{2}$ & 1 & 1 \\
\hline vanilla $^{3}$ & - & 0.2 \\
\hline \multicolumn{3}{|l|}{ Nutrient, DM basis } \\
\hline $\mathrm{DM}, \%$ & 88.4 & 88.5 \\
\hline $\mathrm{NE}_{\mathrm{M}}{ }^{4}, \mathrm{Mcal} / \mathrm{kg}$ & 1.97 & 1.97 \\
\hline $\mathrm{NE}_{\mathrm{G}}^{4}, \mathrm{Mcal} / \mathrm{kg}$ & 1.32 & 1.32 \\
\hline crude protein, $\%$ & 20.4 & 20.2 \\
\hline ether extract, \% & 2.9 & 2.9 \\
\hline NDF, $\%$ & 19.0 & 18.7 \\
\hline $\mathrm{ADF}, \%$ & 11.7 & 11.6 \\
\hline $\mathrm{Ca}, \%$ & 0.77 & 0.75 \\
\hline $\mathrm{P}, \%$ & 0.53 & 0.53 \\
\hline
\end{tabular}

isonitrogenous. Lucerne hay used in starter was chopped and sorted by particle size using a Penn State Forage Separator as described by Lammers et al. (1996). Hay particles were approximately 8 to $19 \mathrm{~mm}$ in length. Ad libitum water was provided for calves from $3 \mathrm{~d}$ of age throughout the study. This study was conducted at the calf raising facilities of the Kenebist dairy farm (Kenebist, Mashad, Iran) from August through October 2007. The average air temperature was $22.3 \pm 9.1{ }^{\circ} \mathrm{C}$, and relative humidity was $44 \pm 12 \%$ during the study. The animals were cared for according to the guidelines of the Iranian Council of Animal Care (1995).

\section{Sample collection and statistical analysis}

Milk intake and starter consumption were measured daily. Body weight was measured at birth, at the three days age (the beginning age of experiment) and then 
weekly throughout the study, at a constant time of the day. Starters were sampled weekly, composited, and frozen at $-20^{\circ} \mathrm{C}$ before analysis for crude protein, ether extract, ADF, NDF, Ca and P according to AOAC methods (1990). Starter and starter residuals were sampled daily, composited weekly and dried weekly in a air-forced oven at $100^{\circ} \mathrm{C}$ for $6 \mathrm{~h}$ and these data were used to determine daily DMI each week.

Faecal consistency was subjectively scored once daily using a scale of 1 (normal faecal consistency) to 4 (severe scours) according to the method of Larson et al. (1977). When faecal material was unavailable for scoring, calves were assigned a missing value. A scour day was defined when calves had a faecal score $>2$. Electrolyte therapy was initiated when calves had faecal score $>2$ and continued until signs of dehydration diminished.

Starter dry matter intake, feed efficiency, faecal scores and days with faecal scores $>2$ data were analysed as completely randomized experimental design using repeated measures ANOVA by the Mixed Procedure of SAS (1998) and the treatments effects within weeks tested by Estimate Procedure of SAS (1998). Calfwithin-treatment was included in the model as a random effect. The covariance structure was modelled according to Littell et al. (1998), and unstructured covariance was selected. Body weight, average daily gain (ADG) and weaning age data were analysed as a completely randomized experimental design using the GLM procedure of SAS (1998). Significance was declared at $\mathrm{P}<0.05$ unless otherwise noted. Results were presented as least square means \pm standard errors of mean differences.

\section{RESULTS}

Starter DMI of calves fed different diets are presented in Table 2. All milk provided was consumed by calves during the preweaning phase, therefore, the only component of DMI that could vary was starter intake. Increased starter DMI was observed for calves fed $\mathrm{F}$ starter during the preweaning period. This effect did not carry over into the postweaning phase, but this increase was observed over the entire experiment for calves fed F starter. Starter DMI was higher during wk 3 to 8 for calves fed $\mathrm{F}$ starter (Table 2). Weaning age was based on starter intake and was attained 2 to $3 \mathrm{~d}$ earlier $(\mathrm{P}<0.03)$ when $\mathrm{F}$ starter was fed $(60.3$ and $57.7 \mathrm{~d}$ for calves fed UF and F starter, respectively).

Body weight was not significantly different between calves of two groups at birth (Table 3 ) but the calves fed $\mathrm{F}$ starter had significantly higher weight at weaning $(\mathrm{P}<0.03)$ and at the end of study $(\mathrm{P}<0.02)$. ADG over the preweaning phase was significantly $(\mathrm{P}<0.01)$ higher for calves fed $\mathrm{F}$ starter (Table 4$)$. No 
differences in ADG were observed postweaning or over the entire experiment due to treatment.

Table 2. Starter dry matter intake by calves fed different diets

\begin{tabular}{lrrrr}
\hline \multirow{2}{*}{ Item } & \multicolumn{2}{c}{ Diet, $\mathrm{g} / \mathrm{d}^{1}$} & \multirow{2}{*}{$\mathrm{SEM}^{2}$} & \multirow{2}{*}{$\mathrm{P}$} \\
\cline { 2 - 3 } Week of study & $\mathrm{UF}$ starter & $\mathrm{F}$ starter & \\
1 & 10.0 & 12.0 & 1.0 & $\mathrm{NS}^{3}$ \\
2 & 47.2 & 50.2 & 2.0 & $\mathrm{NS}$ \\
3 & 130.2 & 148.1 & 8.0 & 0.04 \\
4 & 190.3 & 220.0 & 10.0 & 0.03 \\
5 & 270.8 & 320.0 & 14.0 & 0.03 \\
6 & 390.2 & 430.0 & 17.1 & 0.04 \\
7 & 630.5 & 690.2 & 20.2 & 0.02 \\
8 & 1020.1 & 1090.6 & 30.1 & 0.04 \\
9 & 1300.2 & 1410.2 & 70.2 & $\mathrm{NS}$ \\
10 & 1810.5 & 1900.7 & 10.2 & $\mathrm{NS}$ \\
11 & 2210.2 & 2230.1 & 12.6 & $\mathrm{NS}$ \\
12 & 2780.3 & 2770.8 & 13.5 & $\mathrm{NS}$ \\
Growth period & & & \\
preweaning & 400.2 & 440.5 & 10.2 & 0.03 \\
postweaning & 2120.0 & 2250.7 & 121.0 & $\mathrm{NS}$ \\
overall & 1050.0 & 1250.4 & 82.6 & 0.02 \\
\hline${ }^{1}$ UF - unflavoured; F - flavoured starter; ${ }^{2}$ SEM - standard error of the means; ${ }^{3} \mathrm{NS}$ - non significant
\end{tabular}

Calves fed $\mathrm{F}$ starter were more efficient in converting diet DM to gain than calves fed UF starter during the preweaning phase but no differences in feed efficiency were observed during the postweaning period and also when data were expressed over the entire experiment (Table 3). No significant difference in the faecal scores and number of days with faecal scores $>2$ was found for calves fed different diets throughout the study (Table 3).

\section{DISCUSSION}

Although a few studies have looked at applying flavours in feed to increase the acceptance and intake of certain feeds, vanilla flavour in calf starter has not been examined. Vanilla has a milk like flavour and may increase the intake of starter.

Calves supplemented with vanilla in starter consumed more starter/d, during the preweaning phase and throughout the experiment than calves not supplemented with this flavour agent. This greater starter DMI probably accounted for the enhanced weaning BW and the final BW seen in this study. Despite the different preweaning $\mathrm{ADG}$, there were no differences between the postweaning ADG of calves fed $\mathrm{F}$ 
Table 3. Body weight (BW), average daily gains (ADG), feed efficiency, faecal scores and days with faecal scores $>2$ of calves fed different diets

\begin{tabular}{|c|c|c|c|c|}
\hline \multirow{2}{*}{ Item } & \multicolumn{2}{|c|}{ Diet $^{1}$} & \multirow{2}{*}{$\mathrm{SEM}^{2}$} & \multirow{2}{*}{$\mathrm{P}$} \\
\hline & UF starter & F starter & & \\
\hline \multicolumn{5}{|l|}{ Body weight, $\mathrm{kg}$} \\
\hline birth & 40.20 & 41.0 & 0.60 & $\mathrm{NS}^{3}$ \\
\hline weaning & 61.50 & 64.40 & 0.80 & 0.03 \\
\hline overall & 79.20 & 82.60 & 1.0 & 0.02 \\
\hline \multicolumn{5}{|l|}{$A D G, \mathrm{~kg}$} \\
\hline preweaning & 0.33 & 0.40 & 0.02 & 0.01 \\
\hline postweaning & 0.86 & 0.92 & 0.03 & NS \\
\hline overall & 0.44 & 0.47 & 0.02 & NS \\
\hline \multicolumn{5}{|l|}{ Feed efficiency ${ }^{4}$} \\
\hline preweaning & 0.38 & 0.43 & 0.02 & 0.04 \\
\hline postweaning & 0.40 & 0.41 & 0.02 & NS \\
\hline overall & 0.34 & 0.31 & 0.02 & NS \\
\hline Faecal scores & 1.56 & 1.69 & 0.09 & NS \\
\hline Days with faecal scores $>2$ & 4.6 & 5.2 & 0.31 & NS \\
\hline
\end{tabular}

${ }^{1,2,3}$ see in Table $2 ;{ }^{4}$ ratio of ADG, $\mathrm{kg}$ to DMI (starter and milk), $\mathrm{kg}$

and UF starters and this concurs with no significantly increase in starter intake at postweaning period and shows vanilla flavour has been an effective agent to increase performance before weaning, but not after that. Because starter intake increases sharply after weaning, for example one week after weaning usually a 75$100 \%$ increase in starter intake relative to weaning is observed (Kertz, 2007), as our results also were almost in accordance with these findings (Table 2), it seems that the importance of an intake stimulator will relieve after weaning and calves are able to consume enough solid matters to meet their requirements. Greater intake observed in F starter fed calves implied that the calves reached the weaning criteria at an earlier age and this may provide the producer with a more cost efficient production. Attempts to make feed more palatable are commonly done with many farm animals. For example, molasses is often used in commercial calf starters to increase palatability and feed intake in growing calves. Hereford steers were found to consume more feed when it was flavoured compared with unflavoured feed (Wallace and Riggs, 1967). Similar results were observed with dairy calves when butter, milk aroma and maple flavours were added to milk replacer and calf starter (Thomsen and Rindsig, 1980), as starter intake and weight gain were greater in calves fed flavoured starter than calves offered unflavoured starter. Morrill and Dayton (1978) also reported that calves consumed more feed and gained more weight when offered ethyl butyrate, butterscotch, maple and saccharin flavours in their milk and starter. Flavours can improve the initiation of feed intake and consequently increase weight gain in animals and constitute an important technique 
to advance feeding programmes. We have shown here that the vanilla flavour could stimulate starter intake and BW gain, specially at preweaning period, when included in the calf starter. Although Thomas et al. (2007) did not find any effect of vanilla flavour on feed intake and weight gain of calves, they used flavour in the drinking water and not in the starter.

There was a minimal occurrence of scours by the calves on both treatments, and there were no significant differences in faecal score between treatments. Faecal score less than 2 occurred in calves on each treatment, which is recognized as normal in the growing calf and shows that calves were in healthy and normal conditions throughout the study.

\section{CONCLUSIONS}

The results of this study indicated that addition of the vanilla flavour to starter increased feed intake of calf starter and improved average daily gain specially at preweaning period, so it can be a promising approach to decrease the weaning age of dairy calves and therefore more cost efficient calf rearing.

\section{REFERENCES}

Anderson K.L., Nagaraja T.G., Morrill J.L., 1987. Ruminal and metabolic development in calves weaned conventionally or early. J. Dairy Sci. 70, 1000-1005

AOAC, 1990. Association of Official Analytical Chemists, Official Methods of Analysis. 15 $5^{\text {th }}$ Edition. Arlington, VA

Davis C.L., Drackley J.K., 1998. Starter feed: Importance, composition, and intake. In: The Development, Nutrition and Management of the Young Calf. Iowa State University Press, Ames, pp. 283-306

Iranian Council of Animal Care, 1995. Guide to the Care and Use of Experimental Animals, Vol. 1. Isfahan University of Technology, Isfahan (Iran)

Kertz A.F., 2007. Don't drop the ball when you wean calves. The Hoards Dairyman. W.D. Hoard \& Sons Company, Fort Atkinson, Wisconsin. 10 May, pp. 340-341

Lammers B.P., Buckmasters D.R., Heinrichs A.J., 1996. A simple method for the analysis of particle sizes of forage and total mixed rations. J. Dairy Sci. 79, 922-928

Larson L.L., Owen F.G., Albright J.L., Appleman R.D., Lamb R.C., Muller L.D., 1977. Guidelines toward more uniformity in measuring and reporting calf experimental data. J. Dairy Sci. 60, 989-991

Littell R.C., Henry P.R., Ammerman C.B., 1998. Statistical analysis of repeated measures data using SAS procedures. J. Anim. Sci. 76, 1216-1231

Morrill J.L., 1984. Research in dairy calf nutrition. In: Cornell Nutrition Conference. Feed Manufacture. Syracuse, NY, pp. 46

Morrill J.L., Dayton A.D., 1978. Effect of feed flavor in milk and calf starter on feed consumption and growth. J. Dairy Sci. 61, 229-232 
NRC, 2001. Nutrient Requirements of Dairy Cattle. $7^{\text {th }}$ revised Edition. National Academy of Sciences. Washington, DC

SAS, 1998. SAS User's Guide. Version 7. SAS Institute Inc. Cary, NC

Thomas L.C., Wright T.C., Formusiak A., Cant J.P., Osborne V.R., 2007. Use of flavored drinking water in calves and lactating dairy cattle. J. Dairy Sci. 90, 1-7

Thomsen N.K., Rindsig R.B., 1980. Influence of similarly flavored milk replacers and starter on calf starter consumption and growth. J. Dairy Sci. 63, 1864-1888

Wallace J.D., Riggs J.K., 1967. Moisture, flavor, color and feed acceptability by cattle. J. Anim. Sci. 26, 209 (Abstr.)

Warner R.G., 1991. Nutritional factors affecting the development of a functional ruminant - A historical perspective. In: Proceedings of Cornell Nutrition Conference. Cornell University, Ithaca, NY, pp. 1-12

Winter K.A., 1978. Response to weaning at two to five weeks of age by the young dairy calf. Can. J. Anim. Sci. 58, 377-383 